\title{
A SYSTEM DYNAMICS MODEL TO DETERMINE THE VALUE OF INVENTORY HOLDING COST
}

\author{
BABATUNDE OMONIYI ODEDAIRO ${ }^{* 1}$, EMILOLA HELEN ALABA ${ }^{1}$, \\ INYENEOBONG EDEM ${ }^{1}$
}

\author{
${ }^{1}$ Department of Industrial and Production Engineering, Faculty of Technology, University \\ of Ibadan, Oyo State, Nigeria
}

\begin{abstract}
Traditionally, Inventory Holding Cost (IHC) is assumed to be a combination of several costs and determined by the summation of these cost components. Several authors have suggested that the value of IHC ranges between $12-50 \%$ of the procurement cost of an item. However, due to the absence of a generally acceptable methodology, many practitioners still determine this percentage based on estimates, benchmarks and intuition. Giving considerations to this reality, a mathematical model to determine the value of IHC using systems dynamics approach was developed. IHC was viewed holistically to identify relevant quantities, their interactions (static or dynamics), behaviour and consequences. A Causal Loop Diagram (CLD) was developed to establish the relationship among these quantities. Thereafter, CLD was transformed into a Flow Diagram (FD). FD was used to formulate a set of systems dynamics equations to obtain IHC. The interaction among fraction of goods ordered per month (FOM), fraction sold per month (FSM) and fraction damaged per month (FDM) was simulated to obtain percentage values of IHC. The value of IHC obtained from the model and simulation analysis ranges between $22.58-25.39 \%$ of the item held in stock. Based on these results, it is concluded that the developed model can be used for simulation and system analysis of the holding cost component of an inventory system under different contextual settings.
\end{abstract}

Keywords: inventory holding cost, system dynamics, causal loop diagram, simulation

\section{INTRODUCTION}

Inventory Holding Cost (IHC) is a variable cost and a required input in the computation of total inventory cost. To determine IHC, Onanuga [1] commented that relevant cost components are ignored by practitioners and inventory managers. Miller [2] and Azzi et al. [3] opined that the decision to ignore these components could be as a result of rigors and complexities associated with mathematical computations.

Foster [4] suggested twenty-seven (27) cost components that should be summed to obtain total inventory holding cost, these components can be categorised into five (capital, storage space, handling equipment, inventory risk and inventory service). Azzi et al. [3] argued that IHC can be derived from the sum of storage and opportunity costs expressed as a percentage of the mean inventory investment. Opportunity cost are cost incurred when capital is tied up in inventory rather than being invested in other business activities. Lambert et al. [5] reduced the categories suggested by Foster [4] into four, they asserted that IHC should include costs that vary with the quantity of inventory stored. Harding [6] classified these components into fixed and variable cost factors while Durlinger [7] opined that the components should be determined based on individual organisation.

\footnotetext{
* Corresponding author, email: bo.odedairo@ui.edu.ng

(C) 2020 Alma Mater Publishing House
} 
To obtain the value of IHC, Teunter et al. [8] commented that practitioners still use estimates, benchmarks and intuition because a generally accepted methodology has not been fully established. This reality had been corroborated in literature with a conclusion that while several studies have been carried out, it is still difficult for managers to estimate the value of IHC [4]. Traditionally, the value of IHC is computed as a fraction of the item held in inventory. For industrial applications, Naddor [9] opined that it should vary between 5-25\% per year. However, depending on the industry type, the value ranges between 12-35\% [5]. Pyke and Cohen [10] estimated the value at $20-50 \%$. In their pull inventory model, Clendenen and Rinks [11] assumed holding cost to be $30 \%$ of the product value. Miller [2] pegged IHC at $25 \%$ of the unit price of an item per annum. From literature, a common number for inventory holding cost is $25 \%$ per annum of the purchasing price of an item [7]. Rajhans et al [12] argued that an accurate estimate can only be derived considering relevant cost components which may vary from industry to industry at different time interval.

Arising from the myriads of different cost components and values of IHC suggested in literature, the interactions (static or dynamic), behaviors and consequences among these components is expected to create a multidimensional problem. Therefore, a holistic approach to ascertain the value of IHC problem will assist to reveal hidden feedback loops and counterintuitive relationship among the components. Systems dynamics (SD) modelling is designed precisely for problems possessing these characteristics [13]. SD focuses on the structure and behaviour of systems with interacting feedback loops [14]. SD can be used to develop and test mathematical models as well as simulation of complex dynamic systems [15]. SD has been applied in different fields including supply chain management [16], cost of quality system [17], strategic cost management [18] and inventory management [19].

Based on the reality that IHC can affect profitability and performance of an inventory system [20], Holsenback and McGill [21] opined that it should be diligently measured. Therefore, in this study, a mathematical model to determine the value of IHC using systems dynamics is formulated.

\subsection{Review of inventory holding cost}

Inventory constitute a wide range of materials with the capability to be packaged, stored, transferred, used for production, etc. Sometimes, it is often referred to as collection of idle resources (tangible and intangible) with monetary values. Some of the reasons to hold inventory cited includes fluctuations in demand, price protection, lead time variability, supplier unreliability and quantity discounts [2, 22]. Furthermore, the need to hold inventory requires that some ancillary supports (i.e. activities) must be provided. These include but not limited to the following: (i) acquisition of warehouse and equipment for inventory handling/storage (ii) inspection and counting of inventory (iii) payment of tax (iv) utilisation of energy in form of light, heat and power. Usually, certain costs will be incurred when these activities are executed. Foster [4] and other authors suggested some cost components, these components are reviewed in Table 1.

Table 1. Components of Inventory Holding Cost suggested by different authors.

\begin{tabular}{|c|c|}
\hline Foster [4] & Other Authors \\
\hline $\begin{array}{l}\text { 1) Taxes on land and building } \\
\text { 2) Taxes on inventory }\end{array}$ & $\begin{array}{l}\text { (i) Taxes on land, building, equipment and inventory were considered altogether as } \\
\text { tax }[2,3,23,24,25] \text {. } \\
\text { (ii)Lambert et al. [5] argued that tax on building is irrelevant because the payment } \\
\text { will continue whether or not inventory is kept. }\end{array}$ \\
\hline $\begin{array}{l}\text { 3) Insurance on inventory } \\
\text { 4) Insurance on building. } \\
\text { 5) Insurance and taxes on equipment }\end{array}$ & $\begin{array}{l}\text { (i) Insurance on land, building, equipment and inventory were considered altogether } \\
\text { as tax }[2,3,23,24,25] \text {. } \\
\text { (ii) Lambert et al. [5] considered only "insurance on inventory" as relevant. }\end{array}$ \\
\hline $\begin{array}{l}\text { 6) Depreciation on building (for owned warehouse). } \\
\text { 7) Depreciation on warehouse installations. } \\
\text { 8) Depreciation on equipment }\end{array}$ & $\begin{array}{l}\text { (i) Rajhans et al. [12] considered them relevant. } \\
\text { (ii) This cost are not relevant because they are not "out of pocket cost" }[23,24] \text {. } \\
\text { (iii) Lambert et al. [5] stated that they are fixed and should not be considered. } \\
\text { Other authors did not give reasons for ignoring these costs. }\end{array}$ \\
\hline $\begin{array}{l}\text { 9) Maintenance and repairs on building. } \\
\text { 10) Maintenance and repair of equipment }\end{array}$ & $\begin{array}{l}\text { (i) These components were considered relevant }[3,12,25] \text {. } \\
\text { (ii) Other authors did not give reasons for ignoring these costs }\end{array}$ \\
\hline $\begin{array}{l}\text { 12) Utility cost (heat, light and water) } \\
\text { 13) Fuel for equipment }\end{array}$ & $\begin{array}{l}\text { (i) This cost were named as "warehouse operating cost" }[23,24] \\
\text { (ii) Miller [2] and Azzi et al. [3] referred to them as "utility cost" } \\
\text { (iii) Other authors did not give reasons for ignoring these costs }\end{array}$ \\
\hline $\begin{array}{l}\text { 13) Janitor, watchman and maintenance salaries } \\
\text { 14) Labour costs of handling and maintaining } \\
\text { stocks } \\
\text { 15) Clerical costs of keeping records }\end{array}$ & $\begin{array}{l}\text { (i) This cost were considered as "Manpower cost" [2] } \\
\text { (ii) Harding [6] referred to these costs as "Personnel cost" } \\
\text { (iii) Ziegler [25] considered these costs as material handling and physical inventory } \\
\text { cost. } \\
\text { (iv) Azzi et al. [3] considered these components as "direct and Indirect labour cost". } \\
\text { (v) Other authors did not give reasons for ignoring these costs }\end{array}$ \\
\hline
\end{tabular}




\begin{tabular}{|c|c|}
\hline Foster [4] & Other Authors \\
\hline 16) Rent (if paid) & $\begin{array}{l}\text { (i) This is considered relevant by all the authors and are referred to as "Storage } \\
\text { space cost", "Storage cost" or "Warehouse cost" }\end{array}$ \\
\hline $\begin{array}{l}\text { 17) Obsolescence of inventory } \\
\text { 18) Physical deterioration of inventory } \\
\text { 19) Pilferage } \\
\text { 20) Losses resulting from inventory price declines }\end{array}$ & $\begin{array}{l}\text { (i) This cost are considered relevant by all the authors. Most authors group them } \\
\text { together as "Risk cost" }\end{array}$ \\
\hline $\begin{array}{l}\text { 21) Employer contribution to social security for all } \\
\text { space, handling and inventory service personnel } \\
\text { 22) Unemployment compensation insurance for all } \\
\text { space, handling and service personnel } \\
\text { 23) Employer contributions to pension plans, group } \\
\text { life, health and accident insurance programs for all } \\
\text { space, handling and inventory service personnel. } \\
\text { 24) A proportionate share of general administrative } \\
\text { overhead, including all taxes, social security, } \\
\text { pension and employer contributions to insurance } \\
\text { programs for administrative personnel }\end{array}$ & (i) Not considered relevant by any of the authors whose literature were reviewed \\
\hline 25) Interest on money invested in inventory & (i) Generally referred to as "Capital cost" or "Opportunity cost" by several authors \\
\hline $\begin{array}{l}\text { 26) Interest on money invested in inventory handling } \\
\text { and control equipment } \\
\text { 27) Interest on money invested in land and building } \\
\text { to store inventory (if owned) }\end{array}$ & (i) Lambert et al. [5] referred to these components as "Capital cost of assets" \\
\hline
\end{tabular}

From Table 1, it is obvious that the components of IHC will largely depend on the type of industry, product offerings, scale of operations, etc. In terms of scale, small and medium industries which often utilize manual warehousing system are likely to incur extra costs from product damage, pilferage, and inspection /counting. Also, these components must be explicitly considered; therefore, some of the components presented in Table 1 were further categorized into fixed cost $\left(F_{c}\right)$, variable cost $\left(V_{c}\right)$ and risk cost $\left(R_{c}\right)$ as presented in Table 2. While fixed and variable costs are relevant to all industries, the latter is dependent on the inventory level while the former is incurred by the reason of keeping inventory. On risk cost, the type of product will determine whether to consider it or not. For example, in machinery and equipment sector, high risk of obsolescence is prevalent due to advances in technology; whereas in the textile industries, obsolescence cost is minimized as products can be remanufactured.

Table 2. Categorization of some IHC components into fixed, variable and risk costs.

\begin{tabular}{|c|c|c|}
\hline Cost components & Description & Category \\
\hline Capital cost of inventory & Cost of the capital tied up or the opportunity cost of investment in inventory. & $\mathrm{F}_{\mathrm{c}}$ \\
\hline Capital cost of assets & Opportunity cost of investment in warehouse and storage equipment (if owned) & $\mathrm{F}_{\mathrm{c}}$ \\
\hline Warehouse cost & Cost of acquiring (renting) a warehouse to store inventory & $\mathrm{F}_{\mathrm{c}}$ \\
\hline Energy cost/ Utility cost & $\begin{array}{l}\text { Cost incurred on utilities required to operate the warehouse and equipment such as electricity, } \\
\text { gas, oxygen, fuel, etc }\end{array}$ & $\mathrm{F}_{\mathrm{c}}$ \\
\hline Maintenance Cost & $\begin{array}{l}\text { Annual maintenance cost and the monthly breakdown maintenance cost on building and } \\
\text { storage equipment }\end{array}$ & $\mathrm{F}_{\mathrm{c}}$ \\
\hline Labour Cost & Salary of all workers involved in inventory management & $\mathrm{F}_{\mathrm{c}}$ \\
\hline Warehouse depreciation cost & Depreciation on building and warehouse installations (if owned) & $\mathrm{F}_{\mathrm{c}}$ \\
\hline $\begin{array}{l}\text { Handling equipment } \\
\text { depreciation cost }\end{array}$ & Depreciation on storage/handling equipment such as shelves, pallets, racks, etc. (if owned) & $\mathrm{F}_{\mathrm{c}}$ \\
\hline Insurance on Warehouse & Insurance paid for storage space. & $\mathrm{F}_{\mathrm{c}}$ \\
\hline Inventory Insurance & Insurance paid for inventory & $\mathrm{V}_{\mathrm{c}}$ \\
\hline Insurance on Storage equipment & Insurance paid for Storage/handling equipment & $\mathrm{F}_{\mathrm{c}}$ \\
\hline Taxes on Inventory & Taxes paid on inventory & $\mathrm{V}_{\mathrm{c}}$ \\
\hline Taxes on Warehouse & Taxes paid on warehouse land and building & $\mathrm{F}_{\mathrm{c}}$ \\
\hline Taxes on Storage equipment & Taxes paid on storage equipment & $\mathrm{F}_{\mathrm{c}}$ \\
\hline Obsolescence cost & This describes the cost attached to the risk of inventory never being used. & $\mathrm{R}_{\mathrm{c}}$ \\
\hline $\begin{array}{l}\text { Product damage/depreciation } \\
\text { and deterioration cost }\end{array}$ & $\begin{array}{l}\text { Cost of product damage due to overcrowding of the warehouse, depreciation due to decline } \\
\text { in price of inventory and deterioration for perishable goods whose life cycle is short }\end{array}$ & $\mathrm{R}_{\mathrm{c}}$ \\
\hline Cost of pilferage/theft & Cost incurred when items stored are stolen. & $\mathrm{R}_{\mathrm{c}}$ \\
\hline $\begin{array}{l}\text { Cost of } \quad \text { Repacking and } \\
\text { Relabelling /Remanufacturing }\end{array}$ & Cost incurred when items are repackaged or remanufactured when damaged & $\mathrm{R}_{\mathrm{c}}$ \\
\hline $\begin{array}{l}\begin{array}{l}\text { Inventory inspection and } \\
\text { counting cost }\end{array} \\
\end{array}$ & $\begin{array}{l}\text { Cost of inspecting and counting during the year especially for inventory which are easily } \\
\text { damaged or have short life cycle }\end{array}$ & $\mathrm{F}_{\mathrm{c}}$ \\
\hline Relocation cost & $\begin{array}{l}\text { Cost of transporting inventory from one warehouse to another in order to prevent } \\
\text { obsolescence }\end{array}$ & $\mathrm{R}_{\mathrm{c}}$ \\
\hline Other business specific cost & This refers to other cost components that are peculiar to individual industries. & $\begin{array}{l}\text { Depends on } \\
\text { the definition } \\
\text { of the cost }\end{array}$ \\
\hline
\end{tabular}




\section{RESEARCH METHOD}

\subsection{Description of inventory holding cost (IHC) problem}

The need to hold inventory could arise when finished goods are ordered (or produced) and the quantity utilised (or sold) is lower ordered quantity. Arising from the decision to hold, activities such as warehousing, maintenance, cleaning service, inspection, disposal, repackaging and personnel management must be implemented. These activities will contribute IHC and if the stocks are not properly monitored, the firm risk loss due to damage, spoilage and obsolescence. Hence, the need to consider these components and opportunities available to obtain an acceptable value of inventory holding cost. In Figure 1, the procedure to investigate the relationships between these components and formulate a mathematical model using system dynamics is presented.

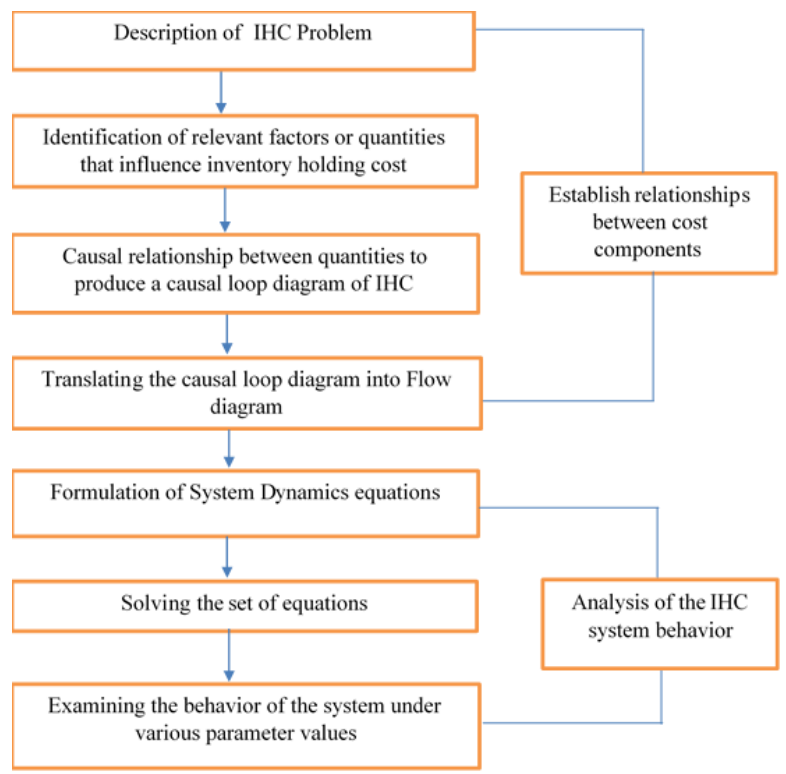

Fig. 1. Procedure for formulation of mathematical model for inventory holding cost.

\subsection{Identification of quantities in inventory holding system}

In Table 3, the quantities in inventory holding system used in this work, notations and their dimensions are listed.

Table 3. Quantities and dimensions.

\begin{tabular}{|c|c|c|}
\hline Quantity & Notation & Dimension \\
\hline Inventory level & INV & \multirow{3}{*}{ Q (quantity) } \\
\hline Desired Inventory level & DINV & \\
\hline Discrepancy & DISC & \\
\hline Replenishment rate & $\mathrm{OR}$ & \multirow{3}{*}{$\begin{array}{l}\frac{Q}{t} \\
\mathrm{t}=\text { time }\end{array}$} \\
\hline Consumption rate & SR & \\
\hline Damage rate & DR & \\
\hline Fraction ordered per month & FOM & \multirow{3}{*}{$\frac{1}{t}$} \\
\hline Fraction sold per month & FSM & \\
\hline Fraction damaged per month & FDM & \\
\hline Unit price of inventory & $\mathrm{P}$ & \multirow{3}{*}{$\frac{\# \text { (Currency) }}{Q}$} \\
\hline Tax rate per unit inventory & $\mathrm{T}_{\mathrm{r}}$ & \\
\hline Insurance per unit inventory & $\mathrm{I}_{r}$ & \\
\hline Average life of warehouse in months & $\mathrm{U}_{\mathrm{w}}$ & \multirow[b]{2}{*}{$\mathrm{t}$} \\
\hline Average life of equipment in months & $\mathrm{U}_{\mathrm{e}}$ & \\
\hline Interest rate & $\mathrm{R}$ & Dimensionless \\
\hline Investment & $\mathrm{I}$ & \multirow{6}{*}{ 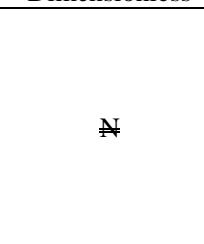 } \\
\hline Capital cost & $\mathrm{C}$ & \\
\hline Insurance on inventory & $\mathrm{I}_{i}$ & \\
\hline Tax on inventory & $\mathrm{T}_{i}$ & \\
\hline Warehouse cost & $\mathrm{W}_{\mathrm{c}}$ & \\
\hline Labour cost & $\mathrm{L}_{\mathrm{c}}$ & \\
\hline
\end{tabular}




\begin{tabular}{|l|c|c|}
\hline \multicolumn{1}{|c|}{ Quantity } & Notation & \multirow{2}{*}{ Dimension } \\
\hline Energy cost & $\mathrm{E}_{\mathrm{c}}$ & \\
\hline Cost of equipment & $\mathrm{C}_{\mathrm{e}}$ & \\
\hline Cost of warehouse & $\mathrm{C}_{\mathrm{w}}$ & \\
\hline Depreciation cost of warehouse & $\mathrm{D}_{\mathrm{w}}$ \\
\cline { 1 - 2 } Depreciation cost of warehouse equipment & $\mathrm{D}_{\mathrm{e}}$ & \multirow{3}{*}{} \\
\cline { 1 - 2 } Insurance on warehouse and equipment & $\mathrm{I}_{\mathrm{w}}$ & \\
\hline Maintenance cost & $\mathrm{M}_{\mathrm{c}}$ \\
\cline { 1 - 2 } Damage cost & $\mathrm{D}_{\mathrm{c}}$ & \\
\hline Inventory Holding cost & $\mathrm{IHC}$ & \\
\hline
\end{tabular}

\subsection{Formulation of mathematical model}

The modeling started with the development of a causal loop diagram (CLD) to depict the dynamic behaviour in the inventory holding system. In this research, CLD is limited to internal factors that influence the inventory holding system. In system dynamics, CLD simplify the illustration of a model and serves as a preliminary sketch. In a CLD, the direction of influence is shown by the arrow, while plus (+) or minus (-) signs indicate the type of relationship between any pair of quantities. The relationship between the quantities is positive if a change in one quantity produces a change in the same direction for the second quantity while the relationship is negative if a change in one quantity produces a change in the opposite direction for the second quantity. Thereafter, CLD is transformed into a flow diagram (FD) to depict rate, state and flow in the inventory holding system. In system dynamics, rate represents an action which brings about a change of the state of the system. State describes the accumulation of resources or the present condition of the system as a result of the rate. Flow represents the direction of flow of rate in or out of the state.

\subsection{Causal loop diagram for IHC}

The CLD in Figure 2 describes a causal relationship between the 30 quantities identified in Table 3.

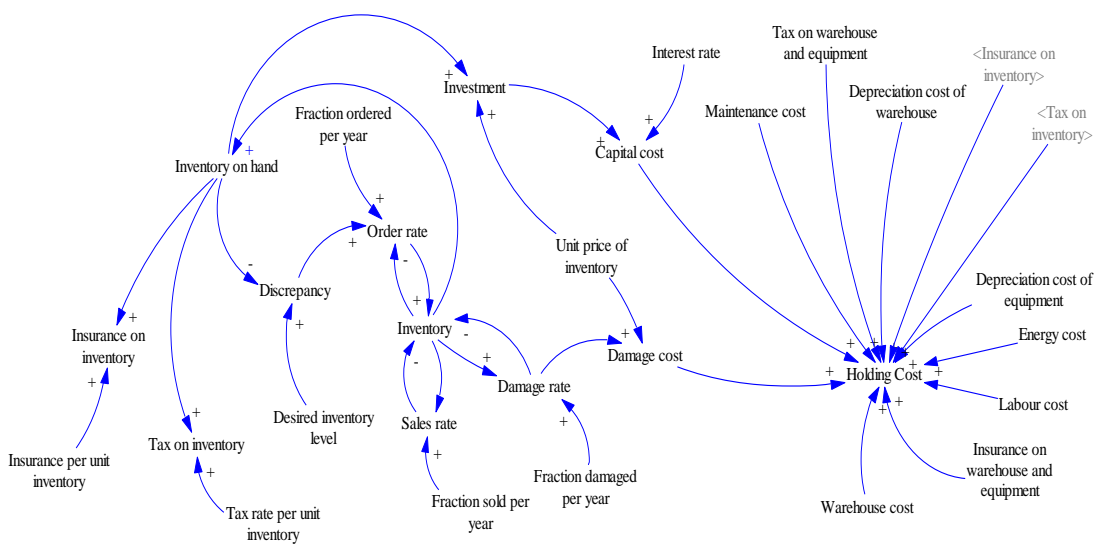

Fig. 2. Causal Loop Diagram for Inventory Holding System.

The CLD revealed that the more the order rate, the more the inventory and the more the sales rate and damage rate. Increase in fraction ordered per month, fraction sold per month and fraction damaged per month resulted in an increase in order rate, sales rate and damage rate, respectively. Furthermore, increase in inventory and unit price of inventory leads to increases in investment. Increase in interest rate and investment caused an increase in capital cost and increase to holding cost.

CLD further revealed that holding cost is dependent on the warehouse cost, labour cost, energy cost, damage cost, tax on warehouse and equipment, insurance on warehouse and equipment, depreciation on warehouse, depreciation on equipment, tax on inventory, insurance on inventory, and maintenance cost

\subsection{Flow diagram}

In system dynamics, rate represents an action which brings about a change in the state of the system, state describes the accumulation of resources or the present condition of the system as a result of the rate, and flow represents the direction in or out of the state. In Table 4, the rates, state, inputs, auxiliary, output and symbols required to construct a FD are described. The CLD highlighted in Figure 2 was transformed into flow diagram presented in Figure 3. 
Table 4. Components of IHC Flow diagram and their Notations.

\begin{tabular}{|c|c|c|c|}
\hline $\mathrm{S} / \mathrm{N}$ & Quantity Type & Quantity & Notation \\
\hline \multirow{3}{*}{1.} & \multirow{3}{*}{ Rates } & Replenishment rate & OR \\
\hline & & Consumption rate & SR \\
\hline & & Damage rate & DR \\
\hline 2. & State & Inventory level & INV \\
\hline \multirow{18}{*}{3.} & \multirow{18}{*}{ Inputs } & Fraction ordered per month & FOM \\
\hline & & Fraction sold per month & FSM \\
\hline & & Fraction damaged per month & FDM \\
\hline & & Desired Inventory level & DINV \\
\hline & & Interest rate & $\mathrm{R}$ \\
\hline & & Unit price of inventory & $\mathrm{P}$ \\
\hline & & Insurance per unit inventory & $\mathrm{I}_{\mathrm{r}}$ \\
\hline & & Tax rate per unit inventory & $\mathrm{T}_{\mathrm{r}}$ \\
\hline & & Tax on warehouse building and equipment & $\mathrm{T}_{\mathrm{b}}$ \\
\hline & & Insurance on warehouse building and equipment & $\mathrm{I}_{\mathrm{b}}$ \\
\hline & & Warehouse cost & $\mathrm{W}_{\mathrm{c}}$ \\
\hline & & Labour cost & $\mathrm{L}_{\mathrm{C}}$ \\
\hline & & Average life of equipment in months & $\mathrm{U}_{\mathrm{e}}$ \\
\hline & & Cost of equipment & $\mathrm{C}_{\mathrm{e}}$ \\
\hline & & Average life of warehouse in months & $\mathrm{U}_{\mathrm{w}}$ \\
\hline & & Cost of warehouse & $\mathrm{C}_{\mathrm{w}}$ \\
\hline & & Maintenance cost & $\mathrm{M}_{\mathrm{c}}$ \\
\hline & & Energy Cost & $\mathrm{E}_{\mathrm{c}}$ \\
\hline & & Discrepancy & DISC \\
\hline & & Investment & I \\
\hline & & Capital cost & $\mathrm{C}$ \\
\hline & & Insurance on inventory & $I_{i}$ \\
\hline & & Tax on inventory & $\mathrm{T}_{\mathrm{i}}$ \\
\hline 4. & Auxil1arıes & Depreciation cost of warehouse & $\mathrm{D}_{\mathrm{w}}$ \\
\hline & & Depreciation cost of warehouse equipment & $\mathrm{D}_{\mathrm{e}}$ \\
\hline & & Insurance on warehouse and equipment & $\mathrm{I}_{\mathrm{w}}$ \\
\hline & & Insurance on equipment & $\mathrm{I}_{\mathrm{e}}$ \\
\hline & & Damage cost & $\mathrm{D}_{\mathrm{c}}$ \\
\hline 5. & Output & Total Inventory Holding cost & TIHC \\
\hline & & mbols used in the construction of flow diagram & \\
\hline & 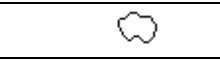 & Source & \\
\hline & 8 & Rate & \\
\hline & $\longrightarrow$ & Flow & \\
\hline & $\longrightarrow$ & Information & \\
\hline & $\square$ & Stare or Stock & \\
\hline
\end{tabular}




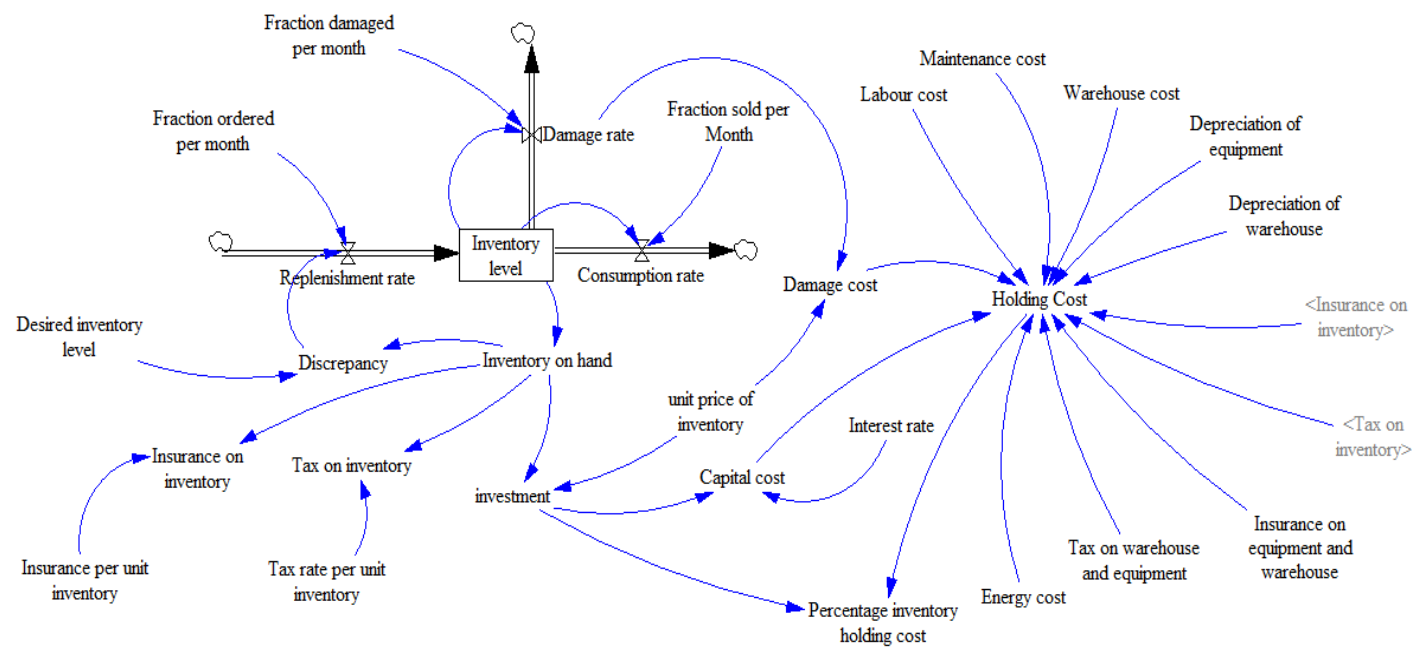

Fig. 3. Flow Diagram for IHC.

\subsection{Formulation of system dynamics equations for inventory holding cost}

\subsubsection{Model assumptions}

The following assumptions guided the development of the model:

1. Inventory items are replenished instantaneously;

2. Time period is monthly.

\subsubsection{Quantity type equations}

\subsubsection{Rate equations}

The rate of change (RC) of the inventory level is expressed as:

$$
\mathrm{RC}=\text { inflow }- \text { outflow }=d I N V / d t=(\mathrm{OR}-\mathrm{SR})-\mathrm{DR}
$$

Considering the principle of dimensional consistency and dynamic equation formulation procedure, the equations for the order rate, sales rate and damage rate were developed as shown in equations (2), (3) and (4).

$$
\begin{aligned}
& \mathrm{OR}=F O M^{*} D I S C \\
& \mathrm{SR}=F S M^{*} I N V \\
& \mathrm{DR}=F D M^{*} I N V
\end{aligned}
$$

Substituting equations (2), (3) and (4) into (1) yields equation (5).

$$
\mathrm{RC}=\left(F O M^{*} D I S C\right)-\left(F S M^{*} I N V\right)-\left(F D M^{*} I N V\right)
$$

Equation (5) can be rearranged as described in equation (6):

$$
\mathrm{RC}=\left(F O M^{*} D I S C\right)-(F S M+F D M) * I N V
$$

\subsubsection{Auxiliary equations}

The auxiliary equations are developed from equations (7) to (15):

Discrepancy:

$$
D I S C=D I N V-I N V
$$

Investment:

$$
\mathrm{I}=I N V^{*} P
$$


Capital cost:

$$
\mathrm{C}=I^{*} R=I N V^{*} P^{*} R
$$

Insurance on inventory:

$$
\mathrm{I}_{i}=I_{\underline{r}} * I N V
$$

Tax on inventory:

$$
\mathrm{T}_{i}=T_{r} * I N V
$$

Depreciation cost of warehouse:

$$
\mathrm{D}_{\mathrm{w}}=\mathrm{C}_{\mathrm{w}} / \mathrm{U}_{\mathrm{w}}
$$

Depreciation cost of warehouse equipment:

$$
D_{e}=C_{e} / U_{e}
$$

Damage cost:

$$
\mathrm{D}_{\mathrm{c}}=D R^{*} P
$$

Equation (14) can be rewritten when DR from equation (4) is substituted to obtain equation (15):

$$
\mathrm{D}_{\mathrm{c}}=F D M * I N V * P
$$

\subsection{Output equation}

From the flow diagram, the output equation (THIC) can be derived by considering the auxiliary equations and input parameters.

$$
\mathrm{THIC}=\mathrm{C}+\mathrm{W}_{\mathrm{c}}+\mathrm{M}_{\mathrm{c}}+\mathrm{L}_{c}+\mathrm{E}_{\mathrm{c}}+\mathrm{D}_{\mathrm{c}}+\mathrm{D}_{\mathrm{e}}+\mathrm{D}_{\mathrm{w}}+\mathrm{T}_{\mathrm{i}}+\mathrm{I}_{\mathrm{i}}+\mathrm{T}_{\mathrm{b}}+\mathrm{Ib}_{\mathrm{b}}
$$

Substitute equations (9), (10), (11), (12), (13) and (15) into (16) to obtain (17).

$$
\mathrm{THIC}=(I N V * P * R)+\mathrm{W}_{\mathrm{c}}+\mathrm{M}_{\mathrm{c}}+\mathrm{L}_{\mathrm{c}}+\mathrm{E}_{\mathrm{c}}+\left(F D M^{*} I N V^{*} P\right)+\left(\mathrm{C}_{\mathrm{e}} / \mathrm{U}_{\mathrm{e}}\right)+\left(\mathrm{C}_{\mathrm{w}} / \mathrm{U}_{\mathrm{w}}\right)+\left(\mathrm{T}_{\mathrm{r}} * I N V\right)+\left(\mathrm{I}_{\mathrm{r}} * I N V\right)+\mathrm{T}_{\mathrm{b}}+\mathrm{I}_{\mathrm{b}}
$$

2.8. Determination of state variable (INV)

From equation (17), INV is a decision variable which can be obtained using Euler solution method.

$$
\mathrm{S}\left(\mathrm{t}_{i+1}\right)=\mathrm{S}\left(\mathrm{t}_{i}\right)+\Delta \mathrm{RC}\left(\mathrm{t}_{i}\right)
$$

From equation (18), the state variable (S) can be replaced by $I N V$; while $\mathrm{t}_{i}$ is the index dimension of time period where $i=1, \ldots, 12$.

Therefore,

$$
I N V\left(\mathrm{t}_{i+1}\right)=I N V\left(\mathrm{t}_{i}\right)+\Delta \mathrm{RC}\left(\mathrm{t}_{i}\right)
$$

From equation (6), $\mathrm{RC}$ can be rewritten as depicted in equation (20):

$$
\mathrm{RC}=F O M *(D I N V-I N V)-(F S M+F D M) * I N V
$$

From equation (20), $\mathrm{RC}$ can be expressed as function time $\left(\mathrm{t}_{i}\right)$ :

$$
\mathrm{RC}\left(\mathrm{t}_{i}\right)=F O M *\left(D I N V-I N V\left(\mathrm{t}_{i}\right)\right)-(F S M+F D M) * I N V\left(\mathrm{t}_{i}\right)
$$

The state variable, $I N V$ (in equation 19) can be rewritten as presented in equation (22). 


$$
I N V\left(\mathrm{t}_{i+1}\right)=I N V\left(\mathrm{t}_{i}\right)+F O M *\left(D I N V-I N V\left(\mathrm{t}_{i}\right)\right)-(F S M+F D M) * I N V\left(\mathrm{t}_{i}\right)
$$

Clearly, equation (22) can be used to simulate the level of inventory at period $t+1$. Also, decisions in period $t$ is expected to have consequences that will be carried into period $t+1$.

\subsection{Value of inventory holding cost}

Usually, the value of IHC (denoted as v) is computed as a percentage (fraction) of item held in stock as depicted in equation (23).

$$
v=\mathrm{THIC} / \mathrm{I} * 100
$$

\section{RESULTS AND DISCUSSION}

\subsection{Model application and simulation}

To verify the applicability of the model, data was collected from a distribution unit of a selected bottling company located in south west of Nigeria for a period of 12 months (January- December 2019).

The values (in units) of the initial inventory level, desired inventory level, annual quantity of goods ordered, average quantity of goods ordered monthly, annual quantity of goods sold, average quantity of goods sold monthly, annual quantity of goods damaged and average quantity of goods damaged monthly were 8258, 50000, 297196, 24766, 280103, 23342, 21350 and 1779, respectively. Also, the unit price of inventory and tax rate were 1100 and 0.0484 , respectively.

\subsubsection{Model application}

The values of the cost components and total inventory holding cost for the company were computed using equations (9) - (17) as summarised in Table 5.

Table 5. Computation of inventory holding cost.

\begin{tabular}{|l|c|}
\hline Cost component & Amount( $)$ \\
\hline Capital cost & $1,271,732$ \\
\hline Warehouse cost & 105,000 \\
\hline Maintenance cost & 0 \\
\hline Labour cost & $22,583.33$ \\
\hline Energy cost & 726,704 \\
\hline Damage cost & 5,200 \\
\hline Consumables/Utility cost & $49,826.42$ \\
\hline Depreciation on equipment & 0 \\
\hline Depreciation on warehouse & 399.69 \\
\hline Tax on inventory & 0 \\
\hline Insurance on inventory & 0 \\
\hline $\begin{array}{l}\text { Tax on warehouse and } \\
\text { equipment }\end{array}$ & 0 \\
\hline $\begin{array}{l}\text { Insurance on warehouse and } \\
\text { equipment }\end{array}$ & $2,306,445.44$ \\
\hline $\begin{array}{l}\text { Total Inventory Holding Cost } \\
\text { (TIHC) }\end{array}$ & \\
\hline
\end{tabular}

From Table 5, capital cost constituted the largest percentage $(55.13 \%)$ of the holding cost, this amount reaffirmed some observation from literature [7, 26]. Using equation (23), the value of IHC (v) was calculated as $25.39 \%$ (i.e. 2306445.44 /1100*8258).

\subsection{Model simulation}

With $\mathrm{FOM}=1, \mathrm{FSM}=0.9$ and $\mathrm{FDM}=0.08$ derived from the inventory records presented in section 3.1 , $v$ was simulated for 12 months using equation (22) as shown in Table 6. 
Table 6. Simulation results for 0 .

\begin{tabular}{|c|c|c|c|c|c|c|c|}
\hline$t$ & INV & $\mathrm{I}$ & $\mathrm{C}$ & $\mathrm{T}_{i}$ & $\mathrm{D}_{c}$ & $\mathrm{TIHC}$ & $\mathrm{v}$ \\
\hline 0 & 8258 & 9083800 & 1271732 & 399.6872 & 726704 & 2306445 & 25.39 \\
\hline 1 & 41907.16 & 46097876 & 6453703 & 2028.307 & 3687830 & 10451171 & 22.67 \\
\hline 2 & 8930.983 & 9824082 & 1375371 & 432.2596 & 785926.5 & 2469340 & 25.14 \\
\hline 3 & 41247.64 & 45372400 & 6352136 & 1996.386 & 3629792 & 10291534 & 22.68 \\
\hline 4 & 9577.316 & 10535048 & 1474907 & 463.5421 & 842803.8 & 2625784 & 24.92 \\
\hline 5 & 40614.23 & 44675653 & 6254591 & 1965.729 & 3574052 & 10138219 & 22.69 \\
\hline 6 & 10198.05 & 11217860 & 1570500 & 493.5858 & 897428.8 & 2776033 & 24.75 \\
\hline 7 & 40005.91 & 44006497 & 6160910 & 1936.286 & 3520520 & 9990975 & 22.70 \\
\hline 8 & 10794.21 & 11873633 & 1662309 & 522.4398 & 949890.6 & 2920331 & 24.60 \\
\hline 9 & 39421.67 & 43363840 & 6070938 & 1908.009 & 3469107 & 9849563 & 22.71 \\
\hline 10 & 11366.76 & 12503437 & 1750481 & 550.1512 & 1000275 & 3058916 & 24.46 \\
\hline 11 & 38860.57 & 42746632 & 5984528 & 1880.852 & 3419731 & 9713750 & 22.72 \\
\hline 12 & 11916.64 & 13108301 & 1835162 & 576.7652 & 1048664 & 3192013 & 24.35 \\
\hline
\end{tabular}

\subsection{System analysis}

Using the developed model, the effect of changes in FSM (at 0.7, 0.5. 0.3 and 0.1) on THIC was determined. FSM is critical to the system because holding cost is applicable to items held in stock, hence the impact on item at hand is critical to better understand the system.

Clearly, TIHC increases with decrease in the value of FSM as presented in Tables (7), (8), (9) and (10).

Table 7. Computation for $v$ at FSM=0.7.

\begin{tabular}{|c|c|c|c|c|c|c|c|}
\hline$t$ & INV & I & C & $\mathrm{T}_{\mathrm{i}}$ & $\mathrm{Dc}$ & $\mathrm{TIHC}$ & $v$ \\
\hline 0 & 8258.00 & 9083800.00 & 1271732.00 & 399.69 & 726704.00 & 2306445.44 & 25.39 \\
\hline 1 & 43558.76 & 47914636.00 & 6708049.04 & 2108.24 & 3833170.88 & 10850937.91 & 22.65 \\
\hline 2 & 16024.17 & 17626583.92 & 2467721.75 & 775.57 & 1410126.71 & 4186233.78 & 23.75 \\
\hline 3 & 37501.15 & 41251264.54 & 5775177.04 & 1815.06 & 3300101.16 & 9384703.00 & 22.75 \\
\hline 4 & 20749.10 & 22824013.66 & 3195361.91 & 1004.26 & 1825921.09 & 5329897.01 & 23.35 \\
\hline 5 & 33815.70 & 37197269.35 & 5207617.71 & 1636.68 & 2975781.55 & 8492645.69 & 22.83 \\
\hline 6 & 23623.75 & 25986129.91 & 3638058.19 & 1143.39 & 2078890.39 & 6025701.72 & 23.19 \\
\hline 7 & 31573.47 & 34730818.67 & 4862314.61 & 1528.16 & 2778465.49 & 7949918.01 & 22.89 \\
\hline 8 & 25372.69 & 27909961.44 & 3907394.60 & 1228.04 & 2232796.91 & 6449029.30 & 23.11 \\
\hline 9 & 30209.30 & 33230230.08 & 4652232.21 & 1462.13 & 2658418.41 & 7619722.50 & 22.93 \\
\hline 10 & 26436.75 & 29080420.54 & 4071258.88 & 1279.54 & 2326433.64 & 6706581.81 & 23.06 \\
\hline 11 & 29379.34 & 32317271.98 & 4524418.08 & 1421.96 & 2585381.76 & 7418831.55 & 22.96 \\
\hline 12 & 27084.12 & 29792527.86 & 4170953.90 & 1310.87 & 2383402.23 & 6863276.75 & 23.04 \\
\hline Total & & & & & & 89583924.47 & \\
\hline
\end{tabular}

Table 8. Computation for $v$ at FSM $=0.5$.

\begin{tabular}{|c|c|c|c|c|c|c|c|}
\hline $\mathrm{t}$ & $\mathrm{INV}$ & $\mathrm{I}$ & $\mathrm{C}$ & $\mathrm{T}_{\mathrm{i}}$ & $\mathrm{Dc}$ & $\mathrm{TIHC}$ & $\mathrm{v}$ \\
\hline 0 & 8258.00 & 9083800.00 & 1271732.00 & 399.69 & 726704.00 & 2306445.44 & 25.39 \\
\hline 1 & 45210.36 & 49731396.00 & 6962395.44 & 2188.18 & 3978511.68 & 11250705.05 & 22.62 \\
\hline 2 & 23777.99 & 26155790.32 & 3661810.64 & 1150.85 & 2092463.23 & 6063034.48 & 23.18 \\
\hline 3 & 36208.77 & 39829641.61 & 5576149.83 & 1752.50 & 3186371.33 & 9071883.41 & 22.78 \\
\hline 4 & 28998.92 & 31898807.86 & 4465833.10 & 1403.55 & 2551904.63 & 7326751.03 & 22.97 \\
\hline 5 & 33180.63 & 36498691.44 & 5109816.80 & 1605.94 & 2919895.32 & 8338927.81 & 22.85 \\
\hline 6 & 30755.24 & 33830758.97 & 4736306.26 & 1488.55 & 2706460.72 & 7751865.28 & 22.91 \\
\hline 7 & 32161.96 & 35378159.80 & 4952942.37 & 1556.64 & 2830252.78 & 8092361.55 & 22.87 \\
\hline 8 & 31346.06 & 34480667.32 & 4827293.42 & 1517.15 & 2758453.39 & 7894873.71 & 22.90 \\
\hline 9 & 31819.28 & 35001212.96 & 4900169.81 & 1540.05 & 2800097.04 & 8009416.65 & 22.88 \\
\hline 10 & 31544.81 & 34699296.49 & 4857901.51 & 1526.77 & 2775943.72 & 7942981.75 & 22.89 \\
\hline 11 & 31704.01 & 34874408.04 & 4882417.13 & 1534.47 & 2789952.64 & 7981513.99 & 22.89 \\
\hline 12 & 31611.68 & 34772843.34 & 4868198.07 & 1530.01 & 2781827.47 & 7959165.29 & 22.89 \\
\hline Total & & & & & & 99989925.42 & \\
\hline
\end{tabular}


Table 9. Computation for $v$ at $\mathrm{FSM}=0.3$.

\begin{tabular}{|c|c|c|c|c|c|c|c|}
\hline$t$ & $\mathrm{INV}$ & $\mathrm{I}$ & $\mathrm{C}$ & $\mathrm{T}_{\mathrm{i}}$ & $\mathrm{Dc}$ & $\mathrm{TIHC}$ & $v$ \\
\hline 0 & 8258.00 & 9083800.00 & 1271732.00 & 399.69 & 726704.00 & 2306445.44 & 25.39 \\
\hline 1 & 46861.96 & 51548156.00 & 7216741.84 & 2268.12 & 4123852.48 & 11650472.19 & 22.60 \\
\hline 2 & 32192.46 & 35411700.72 & 4957638.10 & 1558.11 & 2832936.06 & 8099742.02 & 22.87 \\
\hline 3 & 37766.87 & 41543553.73 & 5816097.52 & 1827.92 & 3323484.30 & 9449019.49 & 22.74 \\
\hline 4 & 35648.59 & 39213449.58 & 5489882.94 & 1725.39 & 3137075.97 & 8936294.05 & 22.79 \\
\hline 5 & 36453.54 & 40098889.16 & 5613844.48 & 1764.35 & 3207911.13 & 9131129.72 & 22.77 \\
\hline 6 & 36147.66 & 39762422.12 & 5566739.10 & 1749.55 & 3180993.77 & 9057092.16 & 22.78 \\
\hline 7 & 36263.89 & 39890279.59 & 5584639.14 & 1755.17 & 3191222.37 & 9085226.43 & 22.78 \\
\hline 8 & 36219.72 & 39841693.75 & 5577837.13 & 1753.03 & 3187335.50 & 9074535.41 & 22.78 \\
\hline 9 & 36236.51 & 39860156.37 & 5580421.89 & 1753.85 & 3188812.51 & 9078598.00 & 22.78 \\
\hline 10 & 36230.13 & 39853140.58 & 5579439.68 & 1753.54 & 3188251.25 & 9077054.22 & 22.78 \\
\hline 11 & 36232.55 & 39855806.58 & 5579812.92 & 1753.66 & 3188464.53 & 9077640.85 & 22.78 \\
\hline 12 & 36231.63 & 39854793.50 & 5579671.09 & 1753.61 & 3188383.48 & 9077417.93 & 22.78 \\
\hline Total & & & & & 113100667.91 & \\
\hline
\end{tabular}

Table 10. Computation for $\mathrm{v}$ at $\mathrm{FSM}=0.1$.

\begin{tabular}{|c|c|c|c|c|c|c|c|}
\hline$t$ & INV & I & C & Ti & Dc & TIHC & $v$ \\
\hline 0 & 8258 & 9083800 & 1271732 & 399.69 & 726704 & 2306445.437 & 25.39 \\
\hline 1 & 48513.56 & 53364916 & 7471088 & 2348.06 & 4269193 & 12050239.33 & 22.58 \\
\hline 2 & 41267.56 & 45394315.12 & 6355204 & 1997.35 & 3631545 & 10296356.43 & 22.68 \\
\hline 3 & 42571.84 & 46829023.28 & 6556063 & 2060.48 & 3746322 & 10612055.35 & 22.66 \\
\hline 4 & 42337.07 & 46570775.81 & 6519909 & 2049.11 & 3725662 & 10555229.54 & 22.66 \\
\hline 5 & 42379.33 & 46617260.35 & 6526416 & 2051.16 & 3729381 & 10565458.19 & 22.66 \\
\hline 6 & 42371.72 & 46608893.14 & 6525245 & 2050.79 & 3728711 & 10563617.03 & 22.66 \\
\hline 7 & 42373.09 & 46610399.24 & 6525456 & 2050.86 & 3728832 & 10563948.44 & 22.66 \\
\hline 8 & 42372.84 & 46610128.14 & 6525418 & 2050.85 & 3728810 & 10563888.79 & 22.66 \\
\hline 9 & 42372.89 & 46610176.94 & 6525425 & 2050.85 & 3728814 & 10563899.52 & 22.66 \\
\hline 10 & 42372.88 & 46610168.15 & 6525424 & 2050.85 & 3728813 & 10563897.59 & 22.66 \\
\hline 11 & 42372.88 & 46610169.73 & 6525424 & 2050.85 & 3728814 & 10563897.94 & 22.66 \\
\hline 12 & 42372.88 & 46610169.45 & 6525424 & 2050.85 & 3728814 & 10563897.88 & 22.66 \\
\hline Total & & & & & 130332831.5 & \\
\hline
\end{tabular}

\section{CONCLUSIONS}

In this study, systems dynamics approach was applied to holistically consider the inventory holding cost system and relevant quantities that influence the system. A causal loop diagram was developed to capture the interrelationship among these quantities and a mathematical model for determination of inventory holding cost was formulated based on the established relationship. The percentage of inventory holding cost of the item price obtained from the model ranges between $22.58-25.39 \%$ which is in line with values recommended in literature.

\section{REFERENCES}

[1] Onanuga, O.R., Determination of optimal order quantities for managing inventories with unknown holding cost and storage constraints, Project, University of Ibadan, Nigeria, 2018.

[2] Miller, G.J., Inventory Carrying Costs: Is there a right way to calculate them? Inventory Reduction Report, vol. 8, no. 1, 2001, p. 9-12.

[3] Azzi, A., Battini, D., Faccio, M., Persona, A., Sgarbossa, F., Inventory holding costs measurement: a multicase study, The International Journal of Logistics Management, vol. 25, no. 1, 2014, p. 109-132.

[4] Foster, R.S., What does it cost to carry inventory? National Association of Wholesalers, 1964.

[5] Lambert, D.M., Stock, J.R., Ellram, L.M., Fundamentals of logistics management., 2nd Ed USA, Irwin Mc Graw-Hill, 1998.

[6] https://www.instituteforsupplymanagement.org/files/Pubs/Proceedings/BCHarding.pdf (13.11.2019).

[7] http://www.durlinger.nl/files/artikelen/Inventory-and-Holding-Costs.pdf (13.11.2019).

[8] Teunter, R.H., Van der Laan, E., Inderfurth, K., How to set the holding cost rates in average cost inventory models with reverse logistics, Omega, vol. 28, no. 4, 2000, p. 409-415. 
[9] Naddor, E., Inventory system, John Wiley, 1966.

[10] Pyke, D.F, Cohen, M.A., Multiproduct integrated production-distribution systems, European Journal of Operational Research, vol. 74, 1994, p. 18-49.

[11] Clendenen, G.W., Rinks, D.B., The effect of labour costs holding costs and uncertainty in demand on pull inventory control policies, International Journal of Production Research, vol. 34, 1996, p. 1725-1738.

[12] Rajhans, N.R., Patil, S.B., Kulkarni, P., Mathematical model for calculation inventory carrying cost, IIIE Journal, vol. 8, no. 1, 2015, p. 12-14.

[13] Abass, K.A., Bell, M.G., Systems dynamics applicability to transportation modelling, Transport Operation and Research Article, vol. 28, no. 5, 1994, p. 373-400.

[14] Goodman, M.R., Study notes in systems dynamics, Wright-Allen Press, p. 5, 1974.

[15] Sterman, J.D., Business dynamics: system thinking and modelling for a complex world, McGraw-Hill, Boston, MA, 2000.

[16] Angerhofer, B.J., Angelides, M.C., System dynamics modelling in supply chain management: research review, Simulation Conference, Proceedings, Winter IEEE, vol. 1, 2000, p. 342-351.

[17] Kiani, B., Systems dynamics approach to analyzing the cost factors effects on cost of quality, International Journal of Quality and Reliability Management, vol. 26, no. 7, 2009, p. 685-698.

[18] Aksu, I., Systems dynamics approach as a tool of strategic cost management, The International Journal of Social Sciences, vol. 15, no. 1, 2013, p. 18-30.

[19] Lawrentsius, P.M., Pinagara, F.A., Materials inventory management to reduce holding cost and backlog (systems dynamics approach: a case study), Advances in Economics, Business and Management Research, 11th International Conference on Business and Management Research, vol. 36, 2017, p. 674-687.

[20] Odedairo, B.O., Ladokun, D.S., Varying lot-sizing models for optimum quantity-determination in material requirements planning system, Engineering and Computer Science: Proceedings of the World Congress on Engineering, vol. 2, 2018. p. 490-493.

[21] Holsenback, E.J., McGill, H.J., A survey of inventory holding cost assessment and safety stock allocation, Academy of Accounting and Financial Studies Journal, vol. 11, no. 1, 2007, p. 111-120.

[22] Vrat, P., Materials management, Springer Texts in Business and Economics, 2014.

[23] Magee, J.F., Quantitative analysis of physical distribution systems, The Social Responsibilities of Marketing. American Marketing Association, 1961.

[24] Hadley, G., Whitin, T.M., Analysis of inventory systems, Englewood Cliffs, New Jersey: Prentice Hall, Inc. 1963.

[25] Ziegler, R.E., Criteria for measurement of the cost parameters of an economic order quantity inventory model, PhD thesis, University of North Carolina, 1973.

[26] Berling, P., Holding cost determination: an activity-based cost approach, International Journal of Production Economics, vol. 112, 2008, p. 829-840. 